\title{
E-Government in Marketing a Country: A Strategy for Reducing Transaction Cost of Doing Business in Tanzania
}

\author{
Muhajir Kachwamba (Corresponding author) \\ Department of Economics and Business Administration, University of Agder \\ Service box 422, NO - 4604 Kristiansand, Norway \\ Tel: 47-3814-1299Ｅ-mail: muhajir.a.kachwamba@uia.no \\ Øystein Sæbø \\ Department of Information Systems, University of Agder \\ Service box 422, NO - 4604 Kristiansand, Norway \\ Tel: 47-3814-1626 E-mail: Oystein.sabo@uia.no
}

Received: June 2, 2011 Accepted: August 31, 2011 Published: November 1, 2011

doi:10.5539/ijms.v3n4p2 URL: http://dx.doi.org/10.5539/ijms.v3n4p2

\begin{abstract}
There are limited studies examining the role of Investment Promotion Agencies (IPA's) and their respective marketing techniques used in attracting Foreign Direct Investment (FDI). Using an exploratory case study approach, this article addresses this research gap by exploring the role of e-government as a promotion technique in eliminating barriers to FDI inflows in Tanzania; particularly barriers related to information accessibility and bureaucratic procedures facing foreign investors in acquiring relevant licenses and business permits. The findings indicate that foreign investors utilize information to create knowledge of business environment in the host country, though some additional information may not be found due to informational specificity of a particular investment project. In addition, the findings indicate that implementation of e-government has reduced some monetary and non-monetary transaction costs of complying with government authorities. The article contributes to the existing body of knowledge in the field of marketing by examining the role of e-government services in the public sector marketing within a macro-marketing domain.
\end{abstract}

Keywords: E-government, Transaction cost, FDI, Destination marketing, Investment Promotion Agency, TIC, ZIPA.

\section{Introduction}

Although Foreign Direct Investment (FDI) has grown globally since 1990s, there is still intense competition for foreign investment inflows among various nations (Mudambi, 1998; Oman, 2000; Ulaga, Sharma, \& Krishnan, 2002). Therefore, nations adopt strategic destination marketing techniques to attract FDIs (Dinnie, 2010; Kotler \& Gertner, 2002; Lim, 2007; Metaxas, 2010). Nations are marketing and promoting their countries in the intense competition to attract investors (Azubuike, 2006). One of the promotion techniques adopted by nations through their Investment Promotion Agencies (IPA's) is to supply Internet-based information to investors (Ulaga et al., 2002). The use of Internet by government agencies to provide information and other services to its customers such as firms and citizens is known as e-government (UN \& ASPA, 2002).

Various marketing techniques, such as International trade fairs, advertising and seminars have, traditionally been used to attract FDI. Currently, the advent of Information Communication Technologies (ICT) empower IPAs to develop e-government services to market their countries. Almost every Investment Agency has a website where investors get access to information. The information search cost may thus be minimized, which may increase the likelihood to attract investment. The websites are among the effective promotional techniques utilized by the IPA's, since investors are increasingly using them as sources of information regarding potential investment sites (Gabriel, 2005).

There are various reasons for IPAs to introduce e-government services as a part of their marketing strategy. First, 
the Internet is acknowledged as a powerful market-space that allows marketers to reach global customers, and provide opportunities for a two way interaction between the marketer and customers (Arnott, 2002). In that sense, choosing e-government as a marketing strategy allows IPA's to reach global investors wherever they are located. Secondly, sometimes investors are unsure where to locate their investments. Reliable and available information may influence investors' decisions on where to invest, when they consider several investments locations. Thirdly, agility has become a common terminology of modern competitive business today. Time matters for investors. Investors are likely to divert investment elsewhere if business entry procedures take excessive time due to bureaucracies and administrative barriers. Excessive bureaucratic procedures have remained one of the barriers to investment in some African countries (Wells, 1999) especially bureaucracies brought by the unnecessary forms, signatures and documents (Morisset \& Lumenga-Neso, 2002). E-government services can help to improve IPA's service delivery to investors through online applications of business permits, licenses and tax registration, as a 'one stop shop' service (Morisset \& Lumenga-Neso, 2002) once investors have decided to enter the market.

Despite these potential benefits of introducing e-government services, little attempt has been made in studying how e-government services are used as a part of the IPA's marketing activities to promote FDI. There are limited amount of research conducted examining the role of IPA and respective techniques used in attracting FDI (Harding \& Smarzynska Javorcik, 2007; Loewendahl, 2001; Mudambi, 1998; Wells \& Wint, 2000). Moreover, although some rare studies have focused on assessing the effectiveness of a particular promotion tool on FDI inflows; little attempt has been made to study the effectiveness of a particular promotion tool in eliminating barriers to FDI inflows in the host country, particularly barriers related to investment information accessibility and bureaucratic procedures facing foreign investors (Harding \& Smarzynska Javorcik, 2007; Morisset \& Lumenga-Neso, 2002). This article addresses this gap by exploring the role of e-government as a strategy used by IPAs in eliminating these two barriers towards attracting FDIs. Specifically, the paper focuses on the following exploratory research questions. First: how do foreign investors use online information and services provided by the IPA's for strategic business decisions? Second: how valuable is this information and services as far as foreign investors' information needs are concerned? And finally: does the implementation of e-government reduce information cost and bureaucratic cost in the investment approval process and acquiring relevant business permits?

These research questions are developed based on the following grounds; first, it has been argued that since the choice of a location is always characterized by market imperfections. Thus, an effective investment promotion strategy should decrease information asymmetry (Loewendahl, 2001; Wells \& Wint, 1990). Hence, analyzing how government electronic information solves informational need of foreign investors is crucial. Secondly, it has also been argued that if business entry procedures take excessive time in a given country, potential investors are more likely to divert investments into other potential locations (Morisset \& Lumenga-Neso, 2002). In this regard, exploring how e-government services simplify the approval processes is also important because it gives a qualitative approximation of the value of e-government towards mitigating bureaucracies in acquiring business permits and approvals. The article contributes to the existing body of knowledge in the field of marketing by examining the role of e-government as special application of Internet in public sector marketing within a macro-marketing domain.

The article is organized as follows. The next section introduces the review of literature and current work in the research area. Section 3 briefly introduces the methodology before the findings are presented in section 4 . In Section 5 we discuss the findings, and finally conclusion and practical implications.

\section{Literature Review}

The literature is divided into 5 main sections. The first four introduce key concepts, including location marketing, e-government, Investment promotion and Internet marketing, and transaction cost of doing business. In the fifth section, we briefly introduce current research, in order to identify the existing knowledge and the contribution made by our work.

\subsection{Location Marketing}

As the world becomes competitive, public sector agencies are urged to adopt Strategic Marketing Management in order to raise public awareness of their location attributes and images to various customers such as citizens, tourism and companies (Kotler \& Gertner, 2002; Page \& Hardyman, 1996). Location marketing involves designing a place in order to satisfy the needs of its target markets and thus it succeeds when citizens and business are pleased with their community and the expectations of visitors and investors are met (Kotler, Hamlin, Rein, \& Haider, 2002). In this study, location marketing is used synonymously with destination marketing or 
place marketing and implies the use of marketing principles to attract foreign investors into a particular country. Country branding may be compared with large corporate branding, where investment and tourism opportunities may be seen as the products (Anholt, 2008; Dinnie, 2009). A country in this case is regarded as a product or brand (Anholt, 2010) with a bundle of attributes characterizing the investment location. Brand name recognition by foreign investors is an essential element of investment promotion (Loewendahl, 2001). Therefore, infrastructural attributes of a country such as human, physical, communication and innovation system has implication on the attractiveness of the investment location and quality of inward investments (Cheng \& Kwan, 2000; Loewendahl, 2001).

According to Wells and Wint, an organization (e.g. an IPA) seeking to create competitive strategies for marketing activities can manipulate the 3P's of marketing in their overall marketing programs (Wells \& Wint, 2000). These $3 \mathrm{P}^{\prime} \mathrm{s}$ include the product (intrinsic advantages and disadvantages of the investment site); the price (cost to the investor of locating and operating within the investment site) and promotion (activities related to dissemination of information in attempt to create an image of the investment site and provide investment services for the prospective investor). Under competitive pressure for FDI attraction, place marketers must understand the needs and requirements from potential investors and find ways to address them better than their competitors (Gertner, 2007). In a public sector marketing context, it can be argued that IPAs are marketers using marketing strategies to promote their locations (countries) especially to attract FDI. Marketing in this context implies creating awareness and building up an image of an area to be perceived by potential investors as a reputable location for new investment. Hence, these activities of IPAs to create awareness and informing about investment opportunities may in one hand be termed as marketing communications with the purpose of creating competitive identity (Anholt, 2008).

\subsection{E-Government}

Many government agencies are increasingly embracing e-government as an innovative and necessary form of public service and administration (Koh \& Prybutok, 2003). The advent of Internet technology and successful conduct of electronic commerce (e-commerce) by private companies have motivated public sector organizations to embrace the technology in fulfilling their missions (Lee, Chen, \& Zhang, 2001). Even though the term e-government has no explicitly agreed definition (Halchin, 2004; Schedler \& Scharf, 2001); it is commonly defined as the use of technology, especially Web-based applications to enhance access to and efficiently deliver government information and services (Brown \& Brudney, 2001). E-government efforts may be specified into three broad categories, namely Government-to-Government (G2G), Government-to-Citizen (G2C), and Government-to-Business (G2B).

E-government involves the use of Internet based information technology for delivering government services better, faster, more efficiently and more cost effective (Backus, 2001; Bannister, 2005; DeBenedictis, Howell, Figueroa, \& Boggs, 2002), to reduce transaction costs (Andersen \& Henriksen, 2006). The potential for improvement by introducing e-government in developing countries relates to several areas (Shuppan, 2008), like setting up processes and services, developing necessary rule of laws, and developing process descriptions on how public processes could improve the general provision of public services. Thus, the potential is not only related to the service delivery, but relates also to the preconditions and work needed to structure and prepare the processes to deliver e-government services. E-government may also improve (internal) state efficiency by improved amount and quality of government information retrieval, which could be used to develop policies. Furthermore, e-government could help to improve the finance and taxation systems and to reduce corruption by introducing more effective and transparent finance and taxation system. ICT use can make public administration more democratic and responsible, by allowing citizens to participate in government processes, and offering better control mechanism by providing citizens more and better government information. Finally, e-government could act as a mechanism to improve formalization and facilitate administrative work (Schuppan, 2008).

Contextual understanding and awareness are needed to successfully design and implement e-government services (Heeks, 2002). Thus, successful experiences from one context cannot automatically be successfully transformed into another. Current knowledge in e-government is mainly based on research done on developed countries. Since institutional, cultural and administrative contexts must be considered when introducing e-government, knowledge cannot simply be transferred from developed to developing context (Schuppan, 2008). Research on e-government in developing countries should not be oversimplified by assuming that learning could be drawn from one isolated projects into others, without considering the surrounding context.

Since different government agencies offer different services to their respective customers, their use of ICT will differ depending on their specialized missions and objectives (Koh \& Prybutok, 2003). From an international 
business perspective, the purpose of investment promotion is to reduce the costs of FDI by providing information on the host country, helping foreign investors to get rid of bureaucratic procedures (Harding \& Smarzynska Javorcik, 2007; Wells \& Wint, 2000). Therefore, e-government, in the case of IPAs, implies use of Internet to provide relevant information to respective investors and transactional services for the purposes of reducing information and bureaucratic costs.

\subsection{Investment Promotion and Internet Marketing}

Attracting FDI has become a central function of industrial policies. Therefore, establishing IPAs has also become pivotal for countries' development strategies (Morisset, 2003). Due to intense competition for FDI among nations, IPAs have been mandated a promotional role where application of strategic marketing techniques similar to those in the private business sector marketing have become evident (Loewendahl, 2001; Wells \& Wint, 2000). Promotion in this context implies activities related to information dissemination in an attempt to create positive image of the investment site and provide investment services for the prospective investor (Wells \& Wint, 2000).

Developing countries, especially in Africa, have long faced difficulties to attract FDI, mainly because of negative perceptions to the region (Dupasquier \& Osakwe, 2006; Morisset, 1999). One of the reasons is that African countries often fail to perform well on some drivers to FDI, e.g.; governance, political stability, economic growth, absence of corruption and infrastructure (Asiedu, 2002; Basu \& Srinivasan, 2002; Morisset \& Lumenga-Neso, 2002). Excessive bureaucratic procedures attract corruption and discourage FDI inflows (Morisset \& Lumenga-Neso, 2002). For example, while it takes one day and single procedure to start a business in Denmark, the process for the same activity takes about 29 days and includes 12 different procedures in Tanzania (World Bank, 2008).

Although investment agencies disseminate information necessary for investors through traditionally communication methods such as conferences, exhibitions, advertising, trade mission and brochures, the advent of ICT has allowed the conduct of investment promotion activities via Internet. IPA's use their websites to build images of their countries, especially addressing foreign investors, and develop interactive services such as processing of various business permits and approvals.

IPA's may develop e-government services to improve the Investment Environment through information accessibility of investment laws and regulation, increasing transparency of the administrative system and investment procedures in the host country, and to simplify the process for foreign investors' prediction of the costs of establishing investment projects (Cho, 2003). Provision of accurate and reliable information reduces information cost. E-government has two major benefits due to the provision of information to investors. First, information may reach investors quickly and efficiently regardless of investors' geographical distance. Secondly, IPA's officials and foreign investors may interact extensively through the application process (Harding \& Smarzynska Javorcik, 2007). Apart from information services the IPA's are increasingly using e-government for transactional services. They use ICT applications such as workflow systems and data transfer through Internet as one stop centre for investment approvals. Cost of travel and communication is reduced (Wang, Bretschneider, \& Gant, 2005) because geographical distance is shrunk.

\subsection{Transaction Cost of Doing Business}

Transaction costs can be defined as the effort made by individuals or organizations in terms of, time and various expenditures in order to obtain relevant information for contract negotiation, bargaining and enforcement (Williamson, 1985). Coiera argues that all costs related to search and evaluations are transaction costs (Coiera, 2000). As far as foreign investments are concerned, transaction cost can occur before the business start-up and after the business is in operation. This article focuses on the costs occurring before business start-ups, commonly known as ex-ante transaction cost. Ex-ante transaction costs can be all costs associated with information search (Brian \& Justin, 1996; Standifird \& Marshall, 2000; Zacharakis, 1997); and costs of setting up the business venture, and may include negotiation costs and other costs of obtaining government authorization and approvals for the transaction (Coiera, 2000; Gray \& Jarosz, 1995).

In the case of FDI, foreign investors have to incur some cost prior to business start ups. Since these costs are ubiquitous before business operations, they are considered ex-ante transaction costs. To reduce such costs as part of investment attraction, institutions especially in emerging markets are expected to play a vital role (Hoskisson, Eden, Lau, \& Wright, 2000; Meyer, 2001). In developing countries like Tanzania, where institutional structures lack strong mechanisms for efficient markets, non-monetary transaction costs may be even higher than in developed countries (Nkya, 2009). Therefore, foreign investors planning to enter into emerging markets may face two major ex-ante transaction costs prior to business operations. The first is information cost required to gather all necessary information about foreign markets. The second is entry cost which includes all costs 
required to comply with government procedures and authorization in starting a particular type of business. Entry cost implies all cost related to legal procedures required before a business can officially opens its doors (Djankov, La Porta, Lopez-de-Silanes, \& Shleifer, 2002). Hence, implementation of e-government by IPA's can be interpreted as one of the institutional mechanisms to reduce cost of information and administrative procedures. E-government services can ease access to information such as rules and guidelines which help to clarify specific rights, responsibilities and liabilities to the customer (Ojha, Palvia, \& Gupta, 2008). Such information increases transparency and reduces uncertainty in transacting with the government and hence results into lower transaction cost such as bribes and corruption (Iqbal \& Seo, 2008; Ojha et al., 2008) in getting various business permits and approvals.

\subsection{Previous Studies on Investment Promotion and FDI inflows}

There are various empirical studies focusing on the influence of investment Promotion efforts on FDI inflows. While some studies report that investment promotion leads to FDI inflows, e.g.; (Morisset, 2003; Wells \& Wint, 2000); others studies found that investment promotion are of limited influence, e.g.; (Kindra, Strizzi, \& Mansor, 1998; Wells \& Wint, 2000). While current studies focus on the role of investment promotion on FDI inflows, our study adopts a different approach. Instead of analyzing the impact of e-government on FDI inflows, we here focus on how e-government services may eliminate barriers to FDI inflows in the host country. Although barriers to FDI inflows in host countries are numerous, the focus of this study is on information accessibility and excessive bureaucratic procedures in the approval process. It has been argued that FDI locations are informational driven (He, 2002; Mariotti \& Piscitello, 1995) and thus foreign investors favor those location which are likely to minimize their information and entry costs (He, 2002; Morisset \& Neso, 2002). Moreover, it has been argued that time required in obtaining necessary business licenses, permits and approvals may influence the cost-efficiency of a location both in terms of time and money (Cho, 2003).

IPA's may use e-government services to improve the investment environment through information accessibility, increasing transparency of the administrative system and investment procedures. Based on these premises we argue that there is an indirect relationship between e-government as a promotion tool and FDI inflows. The improvement of these mediating factors may help to attract more FDIs. The following figure summarizes the conceptual framework, which guided this study.

\section{Insert Figure 1}

The above conceptual model depicts that information cost and bureaucratic costs are among the significant barriers towards FDI attraction. Therefore, elimination of these barriers can logically and intuitively be regarded as a way to attract FDI. So, instead of studying the direct linkage between e-government and FDI inflows, the focus of this study is on the two mediating factors between e-government and FDI, i.e.; information cost and bureaucratic cost. Hence, if e-government reduces information and bureaucratic costs; it may be logical to infer that e-government promotes FDI.

\section{Methodology}

A qualitative case study approach was chosen as an appropriate method (GAO, 1990; Yin, 1994a) to gain contextual understanding and investigate the explorative research questions asked. Case studies are the research strategy of choice when "how" questions are posed, where the researcher has little control over actual behavioral events, and where the focus is on "a contemporary phenomenon within some real-life context" (Yin 1994). Similarly, case studies are considered appropriate particularly for practice-based information system problems where research and theory are at their early formative stages (Benbasat, Goldstein, \& Mead, 1987). The choice of Tanzania Investment Centre (TIC) was purposely done because of its reputation as one of the best IPAs in Africa and the world in general due to its effectiveness as 'one stop shop' for investors (Kisembo, 2007). In year 2007, TIC was nominated by the World Association of Investment Promotion Agencies (WAIPA) as one of the best investment agency. On the other hand, Zanzibar Investment Promotion Authority (ZIPA) was chosen based on convenient criterion as a comparative case due to institutional proximity with TIC.

Multiple sources of evidence were used to study the case, following a suggestion from (Yin, 1994b) who recommends the need for triangulation in searching converging evidences in order to increase construct validity. Data collection methods included: report documents studies, semi structured interviews of administrators working at Tanzania Investment Centre (TIC) in Dar Es Salaam and Zanzibar Investment Promotion Authority (ZIPA) in Stone-town, Zanzibar, e-mail interviews with foreign investors; system observation, transcription of e-mail conversations (between potential and actual foreign investors and TIC). The data collection triangulation here involves the consideration of the e-government services provided and their effects from three perspectives: those of the employees in TIC and ZIPA those of the actual investors by the e-mail interviews conducted, those 
of the potential investors by the transcripts of e-mails between them and the TIC, and by direct observation of the systems itself.

Data were collected at two different levels. In the first step, in-depth interviews were conducted with the senior officials of the Tanzania Investment Centre (TIC) and Zanzibar Investment Promotion Authority (ZIPA) to get the insights of the effectiveness of e-government in the approval process. In the second step, a list of foreign investors with interest to invest in Tanzania between 2008 and 2009 was solicited from TIC's E-mail archive. These e-mails sent by foreign investors to the TIC requesting certain information are used as secondary sources because they contain relevant information on investors' feelings and expectations from TIC.

E-mail archival data provide substantial amount of evidences to researchers (Elsayed \& Douglas, 2006; Murray, 2002; Sixsmith \& Murray, 2001) as secondary source of data. Here we included e-mail with the subject 'information request' and identified 7 foreign companies requesting information, based on a process similar to the one employed by Winzelberg (1997). Due to ethical dilemma in qualitative research particularly on participants' anonymity when using e-mail archive (Sixsmith \& Murray, 2001) names of companies and specific information identifying the investor are not displayed.

A textual content analysis of the transcribed interviews and the e-mail conversations were conducted to understand the shape and significance of the information and services at TIC's and ZIPA's web-pages. The second analysis was theoretical: The collected data material was classified according to the conceptual models presented in figure 1 above. This analysis contributes to a broader understanding of our suggested conceptual model and the relation between the introduced theoretical lenses and empirical findings. The methodological approach is represented in figure 2 .

\title{
Insert Figure 2
}

\section{Results}

\subsection{The Case Studies}

\subsubsection{Tanzania Investment Centre}

TIC is the primary agency of Government to coordinate, promote and facilitate investment in Tanzania and to advise the Government on investment related matters. It is the first point of call for potential investors. TIC main functions include obtaining necessary licenses, work permits, visas, approvals, facilities or services, sorting out any administrative barriers confronting both local and foreign investments, securing investment sites, and provide and disseminate up to date information on existing investment opportunities, benefits or incentives available to investors. Based on these activities, TIC performs five major roles as summarized in figure 3 . The main focus in our study relates to the first and last goals performed by TIC. After the informational stage, investors may decide to make investments based on the information at hand and also face bureaucratic procedures in getting various business permits.

\section{Insert Figure 3}

\subsubsection{Zanzibar Investment Promotion Authority}

To demonstrate its commitment to creating a supportive environment for investment, the Government of Zanzibar enacted a new Investment Code in 2004 to establish a one-stop centre, the ZIPA, to act as focal point for investment promotion and facilitation in Zanzibar. The objective of ZIPA is to have Zanzibar be seen in front of investors as an attractive and competitive investment destination. On the other hand, ZIPA is expected to be an efficient agency for investment promotion and facilitation by providing quality services.

ZIPA has two major roles namely investment promotion and investment facilitation. Promotion activities are conducted in various sectors where Zanzibar has competitive advantages. These sectors include inter alia tourism, fishing and agriculture. On the other hand, facilitation activities include services to facilitate acquisition of work and business permits; land and various incentives. In order to improve the business investment climate, ZIPA is working in collaboration with other International and professional organization such as UNIDO, MIGA, UNCTAD, UNDP and WAIPA.

\subsection{Foreign Companies' Descriptions}

From the analysis of e-mail's texts and communication between foreign investors and TIC; it was found that Owners of the companies investigated came from 7 different countries and were planning to invest into 6 different sectors as shown in Table 1.

\author{
Insert Table 1
}




\subsection{Use and Value of Website Information for Strategic Investment Decisions}

All the companies had used the website for information search to address various informational needs such as: information on procedures to establish a whole owned company or joint ventures companies, bankable project, various business rules and regulations, procedures for obtaining various business permits, taxation systems, opportunities for joint venture formation, costs related to operating in a particular location and industry performance data. General information on e.g. procedures, rules and regulations, taxation systems, and joint venture opportunities were provided online. Our findings indicate that important information needs were not addressed by the information available at the website and therefore potential investors had to request additional information from the IPA's through other sources, such as through e-mail communication. The information not found online includes cost estimates of operating in a particular location, industry performance data and industry competitiveness. This is due to the fact that different investment projects require more project specific information.

General information is more easily accessible in the websites than industry specific information. As will be noted later, both types of information are considered to be of critical importance to foreign investors. Although the findings show that investors requested additional information, especially information on industry competitiveness, there is a possibility that this type of information cannot be obtained from an investment agency. For example, TIC can provide a list of competitors in a particular industry but not sensitive information on what each competitor is exactly doing, as argued by one of TIC's official:

'One of our roles is to protect investors' intellectual property rights. If an investor asks, how many players are in the ICT sector and what exactly each player is doing? TIC officials will only provide information on the number of player but not what players are exactly doing. We will advise the investor to conduct own research because it is our obligation to keep secrecy of investors' (TIC, Director of Research \& Information system).

The implication from these findings is that only part of the information cost can be reduced by website information and thus foreign investors may be required to complement website information with other sources of information. This was evident in the communication between investors and IPA's. Apart from searching information on the website foreign investors were seeking information from Tanzanian embassies abroad. The following excerpt is from the communication between TIC and a foreign company:

'With reference to the information on your website and our meeting with the Minister at the Tanzanian High Commission; we have learnt that your organization helps in promoting investment opportunities and setting up of new businesses in Tanzania. Our initial market survey concludes that we can manufacture \& market our products to the African continent making Dar Es Salaam as our base of operations' (From an Investor based in India).

Foreign investors found the available information useful, even though some explicit information was not to be found. Words such as 'useful information in the website'; 'wonderful ideas and knowledge in the website' were common in the communication and signal the value of the website information. The following excerpt is an example from an e-mail from a potential investor:

'I just had a look at your website and saw that you have a lot of useful information on investment opportunities in Tanzania. Do you have any information or data about the poultry industry in Tanzania? Could you perhaps get us in touch with either a list of private companies in this sector or the Ministry that is responsible for poultry'? (From a Dutch Consultancy firm based in Kenya).

Investors were being informed about available bankable projects and joint venture opportunities through the websites. List of bankable projects were grouped into 5 sectors namely energy, manufacturing, mining \& petroleum, tourism and transport. Similarly, in ZIPA's website, investors were being informed about eligibility based on minimum capital criterion by sectors and various incentive packages. Foreign investors use website information to create knowledge on joint venture opportunities, investment opportunities, incentives offered, business contacts and procedures to obtain various business permits such as licenses, work permits, visas and tax registrations.

\subsection{The Approval Process between Pre and Post e-government Period}

Bureaucratic barriers are major barriers hindering foreign investment; that is why TIC and ZIPA are developing their 'one stop shop' services. The agencies try to lower bureaucratic barriers in acquiring various permits. The process of getting the businesses up and running in a foreign country is traditionally characterized by intense government bureaucracies, as commented upon one interviewee:

'The final objective is to make sure that once the investor lands is detached from the government bureaucracies 
so that the process of getting the business up and running becomes easier. Therefore, our main objective is to make sure that TIC is a 'one stop shop" (TIC, Director of Research \& Information system).

The concept of 'one stop shop' implies that all investment approving bodies such as Ministry of land (land), Migration (visas and work permits), and Revenue authority (taxation) and company registration (business permits) are located at TIC and ZIPA.

\subsubsection{Comparing the Nature of the Investment Approval Process at TIC and ZIPA}

A description of the typical investment approval process provides a better understanding of how e-government services are likely to mitigate bureaucratic costs in the process.

\section{- Approvals at TIC}

The entire process of investment approvals at TIC is automated in a special work program called the 'WORKFLOW' system. The typical pattern of the investment approval is that once an investor submits all necessary requirements, the next step is to provide certificate of incentive followed by the project evaluation. Then the decision is made whether the project is approved or disapproved. The whole process is conducted electronically and all TIC officials involved are given a particular role of approving a respective part through the WORKFLOW system. While each officer is responsible to a particular section, all officials can view the movement and status of files in the WORKFLOW system. This keeps all officials being well informed and getting accurate records about status of a particular project. TIC officials can work with the approval process wherever they are around the globe as long as they have access to the Internet. Based on this system, TIC has guaranteed the approval of the project within 7 days although sometimes projects can be approved in less than 3 days.

The use of Internet in the approval process is an example of how e-government services are implemented. The main objective is to make sure that TIC is implementing e-government to support the whole process, as commented by one of the TIC's officials:

'All the approval process is automated. So, we will tend to capture the basic information that is required for evaluation of a specific project. The intention here is to implement e-government as much as we can in performing our functions' (TIC, senior system Administrator).

There is high level of transparency during the approval process, which decreases the delays in the approval processes. The potential investor has the opportunity to login into TIC website and track the application status throughout the process, and identify the officer being responsible. Hence, an investor has an opportunity to know where the file is located or how it moves within TIC's staff and can ask why an officer is sitting with his/her file so long.

\section{- Approvals at ZIPA}

The approving officers are located at ZIPA (similar to TIC), but the entire internal approval process is paper based. While on average TIC approves about 500-600 projects per year, ZIPA approves between 40 and 60 projects per year. Moreover, while it takes about minimum 7 days to get the project approved at TIC; the average minimum time to get the project approved at ZIPA is 21 days. The typical approval process at ZIPA starts by submitting a short business proposal containing information such as company's name, investment capital, targeted sector and market. This document can be submitted by e-mail or any other means of communication.

The website contributes to the approval process by informing investors on relevant procedures and approval processes. After visiting the website, some investors send their applications directly, some ask for more clarification on certain procedures and some set appointments through e-mails. Investors make preliminary decisions at home and mainly visit Zanzibar to finalize the contracts, bringing all relevant documents.

\subsubsection{Before and After Introducing Online Information and Services}

Our findings indicate that there are four major benefits of introducing the e-government services: speed, value for money, cost effectiveness and greater market outreach. Each of these benefits is as described underneath.

Speed: At TIC, the implementation of the e-government services has increased efficiency in the approval process, by reducing the time needed to perform the process. In particular, the introduction of the WORKFLOW system and the 'one stop shop' approach has helped to speed up the process. Now, all officers responsible to approving a particular investment project have an opportunity to work regardless of where they are:

'If you are using the paper files, you can't approve the projects unless you are in the office. But now, my staffs don't need to be in the office in order to approve the project. If you go into my website, there is a special box TIC 
employees' login. When you login you have access to all your offices. You can approve the project even if you are in London as long as your computer is connected to the Internet' (TIC, Director of Research \& Information system).

Value for money to investors and IPAs: The implementation of e-government services increase value for money since the investor now has the opportunity to make necessary preliminary decisions at home before visiting the host country. Preparations and information sharing can be done online without face-to-face meetings. One of the interviewee at ZIPA emphasized on this;

'They get information from our website, then we correspond to each other, negotiate and some submit their application through Internet'(ZIPA, Director of investment promotion \& Services).

Information dissemination cost: Before introducing the website, ZIPA and TIC used various techniques to disseminate information to investors, including brochures, meetings, business magazines, trade missions and DVDs. Although, these techniques are still used, the website is perceived to be cost effective technique relative to other alternatives, as noted by one of the interviewees from ZIPA:

'This is a sample of brochure we were using and still using including advertising in the magazines. Before the website, we used these brochures for promotion or we had to go ourselves outside the country. It was not that effective, difficult and costly'(ZIPA, Investment promotion manager).

Greater outreach: Both TIC and ZIPA have a greater outreach than before. Promotion via the website is not limited by geographical barriers and distance, resulting in a higher number of projects approved per year on one side, but also more diversification of investment inflows from the country of origin as emphasized by one of the interviewees from ZIPA:

'Before the Website, we had investors originating from one or two locations; but now we have diverse. You can see the trend, our investment inflows is now diversified' (ZIPA, Investment promotion manager).

Through the e-government services, investor get relevant information about the investment site and its related attributes, such as opportunities and constraints of the investment location.

For example, 'investors have no time to travel to come to Tanzania to see the investment site before they decide to invest. So, TIC can take a nice picture of a location and show the investors about the infrastructure aspect and the constraints on the location through Internet. Therefore, they can make preliminary decisions before traveling to Tanzania' (TIC, Director of Research \& Information system).

\section{Discussion}

This study explores the role of e-government services introduced at TIC and ZIPA to promote FDI. Specifically, the article focuses on the following exploratory research questions. Do foreign investors use website information for strategic business decisions? How valuable is the website information as far as foreign investors' information needs are concerned? And; does implementation of e-government reduce information cost and bureaucratic cost in the investment approval process and acquiring relevant business permits? These questions are discussed below.

\subsection{Use and Value of Website Information for Strategic Business Decisions}

Our findings revealed that foreign investors used and valued website information to generate knowledge about business environment in the host country. Investors use website information to get knowledge of the available business opportunities, joint venture opportunities, procedures necessary for establishing a particular project and business contacts for additional information. However, the findings also revealed that investors request additional information, which is not available online. Thus, while website information is general to every investor there is still a need for more specific information to address investors' information needs.

Moreover, the findings indicate that while general information on business opportunities and various procedures to establish a business are easily found; information on industry performance and competitive analysis is difficult to obtain. This supports findings of previous studies, for example, Wells (1999) who argues that most investment agencies do better in providing information about the country and procedures to establish businesses. The implication here is that general information can be acquired at zero or very low cost (Mariotti \& Piscitello, 1995). Hence, while website information reduces part of the information cost; foreign investors may be obliged to incur some part of information cost in seeking additional information from alternative sources. For a firm to gain strategic value from information resource, it is imperative to combine both public and private information.

E-government services may mitigate some transaction costs of establishing a business in a foreign country and these costs can be interpreted in economic sense as opportunity costs. For example, if an investor is informed 
about the location and able to make preliminary decisions before visiting the host country, significant resource saving can be gained in terms of time used to travel and transport costs, especially when the geographical distance between the home and host country is large. Such cost saving may be interpreted as opportunity cost since these resources can be allocated by investors into other best alternatives. Some of our findings suggest that part of these costs may still exist, mainly for two reasons. First, as discussed previously, not all information needed by investors can be found in the IPAs website, for example information on industry competitiveness. Secondly, some foreign investors may prefer to visit the host country for face-to-face discussion with government officials even after acquiring important information from the Website and through e-mail communication.

\subsection{Bureaucracies and Efficiency in the Approval Processes}

There have been an increased number of approved projects both at TIC and ZIPA for the last few years. Even though ZIPA does not use Internet services in the approvals, the website is considered important for the increased number of approvals, based on its role for information dissemination. TIC uses Internet for both information and approvals and associates the increase in number of projects with the increased importance of Internet for information dissemination on one side, and the increased efficiency of the internal processes based on the WORKFLOW system on the other.

Our findings indicate that time reduced in the approvals (delay) is directly attributed to the implementation of e-government services, although other causal possible factors cannot be ignored. E-government services facilitates the approval process by connecting various departments within TIC, e.g.; director's office, promotion department, tax, migration, business license and land offices. Separation of these offices can lead to non-transparent and excessive bureaucratic procedures which may discourage investors. The use of e-government services as an institutional tool to reduce bureaucracies and excessive regulatory procedures has been suggested in the literature, e.g. Moriset and Lumenga-Neso (2002) and World Bank (2004).

Based on these findings, we argue that e-government services can reduce cost of doing businesses in Tanzania if properly and intelligently implemented at IPA's. Costs attributed to geographical distance and costs related to bureaucratic procedures might be greatly reduced (Wang et al., 2005). These findings corroborate previous studies, for example, (Cho, 2003) who argues that Investment Agencies can use e-government to improve the Investment Environment through accessibility of investment Laws and regulation, increasing transparency of the administrative system in the approval processes and investment procedures in the host country.

\section{Conclusion and Practical Implication}

Our study contributes to the very limited amount of studies on the impact of e-government services in developing countries. We contribute to this stream of research by reporting from an exploratory case study focusing on the use of e-government services at IPA's. Our exploratory findings suggest that e-government may reduce some information and bureaucratic costs facing foreign investors. In this regard, it logically suffices to hypothesize that e-government may promote FDI. Hence, the advent of ICT and the role it plays at IPA's, qualifies it to be one of the determinants of FDI (Gani \& Sharma, 2003; Gholami, Tom Lee, \& Heshmati, 2006). Various explanations may prevail to include ICT in the FDI models. One of these explanations is to argue for the role of E-government as used by Investment Agencies in reducing information and bureaucratic costs facing foreign investors in host countries.

Our findings have some practical implication for Tanzanian government in its efforts to attract FDI. The concept of IPA's as a 'one stop shop' can be meaningless if the IPAs are not performing the major approvals. The current practice is that officers of major approving bodies are located at IPA's, but are not the final decision makers. Their role is to collect documents from investors and submit them to respective authorities. For example, land officer collects documents from IPA's and submit them to the Ministry of land for approval by the commission for land. To get full advantage of the one-stop shop approach in the approval process; it is imperative to have all major government authorities responsible for investment approvals (e.g.; IPA's, land office, business license office, tax office, labor and migration offices) coordinated and connected by ICT. This may imply connecting all relevant agencies to a compatible system, for instance the WORKFLOW system. By doing so, the number of days to approve and obtain various permits and the quality of the decisions being made can be significantly improved.

\section{References}

Andersen, K. V., \& Henriksen, H. Z. (2006). E-government maturity models: Extension of the Layne and Lee model. Government Information Quarterly, 23(2), 236-248. http://dx.doi.org/10.1016/j.giq.2005.11.008 
Anholt, S. (2008). Place branding: Is it marketing, or isn't it? Journal of Place Branding and Public Diplomacy, 4, 1-6. http://dx.doi.org/10.1057/palgrave.pb.6000088

Anholt, S. (2010). Definitions of place branding- Working towards a resolution. Journal of Place Branding and Public Diplomacy, 6(1), 1-10. http://dx.doi.org/10.1057/pb.2010.3

Arnott. (2002). Internet interaction and implications for marketing. Marketing Intelligence, 20(2), 86. http://dx.doi.org/10.1108/02634500210418509

Asiedu, E. (2002). On the Determinants of Foreign Direct Investment to Developing Countries: Is Africa Different? World Development, 30(1), 107-119. http://dx.doi.org/10.1016/S0305-750X(01)00100-0

Azubuike, A. A. (2006). Accessibility of Government Information as a Determinant of Inward Foreign Direct Investment in Africa. Paper presented at the World Library and Information Congress: 72nd IFLA General Conference and Council.

Backus, M. (2001). E-Governance and Developing Countries: Introduction and Examples IICD Research BriefResearch Report Number 3.

Bannister, F. (2005). E-government and administrative power. Electronic Government, 2(2), 160-176. http://dx.doi.org/10.1504/EG.2005.007092

Basu, A., \& Srinivasan, K. (2002). Foreign Direct Investment in Africa-Some Case Studies. IMF Working Paper, pp. 1-41. [Online] Available: http://ssrn.com/abstract=879545

Benbasat, I., Goldstein, D. K., \& Mead, M. (1987). The case research strategy in studies of information systems. MIS Quarterly, 11(3), 369-386. http://dx.doi.org/10.2307/248684

Brian, F., \& Justin, K. (1996). Transaction costs, externalities and information technology in health care. Health Economics, 5(1), 25-36. http://dx.doi.org/10.1002/(SICI)1099-1050(199601)5:1<25::AID-HEC181>3.0.CO;2-F

Brown, M. M., \& Brudney, J. L. (2001). Achieving advanced electronic government services: An examination of obstacles and implications from an international perspective. Paper presented at the National Public Management Research Conference.

Cheng, L. K., \& Kwan, Y. K. (2000). What are the determinants of the location of foreign direct investment? The Chinese experience. Journal of International Economics, 51(2), 379-400. http://dx.doi.org/10.1016/S0022-1996(99)00032-X

Cho, J.-W. (2003). Foreign Direct Investment: Determinants, Trends in Flow and Promotion Policies. Investment Promotion and Enterprise Development Bulletin for Asia and the Pacific, Vol. 1, UNITED NATIONS.

Coiera, E. (2000). Information Economics and the Internet. Journal of the American Medical Informatics Association, 7, No.3. http://dx.doi.org/10.1136/jamia.2000.0070215

DeBenedictis, A., Howell, W., Figueroa, R., \& Boggs, R. (2002). E-government Defined: An Overview of the Next Big Information Technology Challenge. Issues in Information Systems, 3(1), 130-136.

Dinnie, K. (2009). Nation branding: Concepts, issues, practice. Journal of Brand Management, 16, 582-583. http://dx.doi.org/10.1057/bm.2008.36

Dinnie, K., Melewar, T. C., Seidenfuss, K. U., \& Musa, G. (2010). Nation branding and integrated marketing communications: an ASEAN perspective. International Marketing Review, 27(4), 388-403. http://dx.doi.org/10.1108/02651331011058572

Djankov, S., La Porta, R., Lopez-de-Silanes, F., \& Shleifer, A. (2002). The Regulation of Entry. The Quarterly Journal of Economics, 117(1), 1-37. http://dx.doi.org/10.1162/003355302753399436

Dupasquier, C., \& Osakwe, P. N. (2006). Foreign direct investment in Africa: Performance, challenges, and responsibilities. Journal of Asian Economics, 17(2), 241-260. http://dx.doi.org/10.1016/j.asieco.2005.07.002

Elsayed, T., \& Douglas, O. (2006). Modelling Identity in Archival Collections of Email: A Preliminary Study. Paper presented at the 3rd Conference on E-mail and Anti-Spam, California USA.

Gabriel, M. T. (2005). Measuring the Efficiency of IPAs - An Input View Using DEA, Master thesis. Vienna University of Economics and Business Administration, Vienna.

Gani, A., \& Sharma, B. (2003). The Effects of Information Technology Achievement and Diffusion on Foreign Direct Investment. Perspectives on Global Development \& Technology, 2(2), 161-178. http://dx.doi.org/10.1163/156915003322763548 
GAO. (1990). Case study Evaluations. Program Evaluation and Methodology Division, US General Accounting Office. [Online] Available: http://www.gao.gov/special.pubs/10_1_9.pdf (August, 21st 2011)

Gertner, D. (2007). Place branding: Dilemma or reconciliation between political ideology and economic pragmatism? Journal of Place Branding and Public Diplomacy, 3, 3-7. http://dx.doi.org/10.1057/palgrave.pb.6000053

Gholami, R., Tom Lee, S.-Y., \& Heshmati, A. (2006). The Causal Relationship between Information and Communication Technology and Foreign Direct Investment. World Economy, 29(1), 43-62. http://dx.doi.org/10.1111/j.1467-9701.2006.00757.x

Golden, W., Hughes, M., \& Scott, M. (2003). The Role of Process Evolution in Achieving Citizen Centered E-Government. AMCIS 2003 Proceedings. Paper 100.

Gray, C., W, \& Jarosz, W. W. (1995). Law and the Regulation of Foreign Direct Investment: The Experience from Central and Eastern Europe. Columbia Journal of Transnational Law, 33(1).

Grönlund, Å., \& Anderson, A. (2006). E-gov research quality improvements since 2003: More rigor, but research (Perhaps) redefined. Lecture Notes in Computer Science, 4084, 1. http://dx.doi.org/10.1007/11823100_1

Halchin, L. E. (2004). Electronic government: Government capability and terrorist resource. Government Information Quarterly, 21(4), 406-419. http://dx.doi.org/10.1016/j.giq.2004.08.002

Harding, T., \& Javorcik, S. Developing Economies and International Investors: Do Investment Promotion Agencies Bring Them Together? World Bank Policy Research Working Paper. No. 4339. [Online] Available: http://ssrn.com/abstract=1012217

He, C. (2002). Information costs, agglomeration economies and the location of foreign direct investment in China. Regional Studies, 36(9), 1029 - 1036. http://dx.doi.org/10.1080/0034340022000022530

Heeks, R. (2002). E-Government in Africa: Promise and practice. Information Polity: The International Journal of Government \& Democracy in the Information Age, 7(2/3), 97.

Hoskisson, R. E., Eden, L., Lau, C. M., \& Wright, M. (2000). Strategy in Emerging Economies. The Academy of Management Journal, 43(3), 249-267. http://dx.doi.org/10.2307/1556394

Iqbal, M. S., \& Seo, J.-W. (2008). E-Governance as an anti-corruption tool: Korean Cases. Journal of Korean Association for Regional Information Society, 11(2), 51-78.

Kindra, G. S., Strizzi, N., \& Mansor, N. (1998). The role of marketing in FDI generation: evidence from ASEAN countries. International Business Review, 7(4), 399-421. http://dx.doi.org/10.1016/S0969-5931(98)00018-3

Kisembo, P. (2007). TIC wins top world award. Guardian. [Online] Available: http://www.afdevinfo.com/htmlreports/org/org_15324.html (December 31st, 2008)

Koh, C. E., \& Prybutok, V. R. (2003). The Three Ring Model and Development of an Instrument for Measuring Dimensions of E-Government Functions. Journal of Computer Information Systems, 43(3), 34.

Kotler, P., \& Gertner, D. (2002). Country as brand, products, and beyond: A place marketing and brand management perspective. Journal of Brand Management, 94. http://dx.doi.org/10.1057/palgrave.bm.2540076

Kotler, P., Hamlin, M. A., Rein, I., \& Haider, D. H. (2002). Marketing Asian Places. Singapore: John Wiley \& Sons.

Lim, S. (2008). How investment promotion affects attracting foreign direct investment: Analytical argument and empirical analyses. International Business Review, 17, 39-53. http://dx.doi.org/10.1016/j.ibusrev.2007.09.001

Lin, H., \& Zhang, L. (1998). Internet - based investment environment information system: a case study on BKR of China. International Journal of Geographical Information Science, 12(7), 715. http://dx.doi.org/10.1080/136588198241626

Loewendahl, H. (2001). A Framework for FDI Promotion. Transnational Corporations, 10(1), 1-42.

Mariotti, S., \& Piscitello, L. (1995). Information Costs and Location of FDIs within the Host Country: Empirical Evidence from Italy. Journal of International Business Studies, 26(4), 815-841. http://dx.doi.org/10.1057/palgrave.jibs.8490821

Metaxas, T. (2010). Place marketing, place branding and foreign direct investments: Defining their relationship in the frame of local economic development process. Place Branding and Public Diplomacy, 6, 228-243. 
http://dx.doi.org/10.1057/pb.2010.22

Meyer, E. K. (2001). Institutions, Transaction Costs, and Entry Mode Choice in Eastern Europe. Journal of International Business Studies, 32(2), 357. http://dx.doi.org/10.1057/palgrave.jibs. 8490957

Morisset, J. P. (2003). Does a Country Need a Promotion Agency to Attract Foreign Direct Investment? A Small Analytical Model Applied to 58 Countries. World Bank Policy Research Working Paper No. 3028. [Online] Available: http://ssrn.com/abstract $=636390$.

Morisset, J. P., \& Neso, L., Olivier (2002). Administrative Barriers to Foreign Investment in Developing Countries (No. 2848): World Bank Policy Research Working Paper 2848. Washington.

Morisset, Jacques P. (1999). Foreign Direct Investment in Africa: Policies Also Matter. World Bank Policy Research Working Paper No. 2481. [Online] Available: http://ssrn.com/abstract=632551

Mudambi, R. (1998). The Role of Duration in Multinational Investment Strategies. Journal of International Business Studies, 29(2), 239-261. http://dx.doi.org/10.1057/palgrave.jibs.8490035

Murray. (2002). Qualitative health research via the Internet: practical and methodological issues. Health Informatics Journal, 8(1), 47.

Nkya, E. J. (2009). NON-MONETARY COST OF DOING BUSINESS: Regulatory Compliance in Small-Scale Enterprises in Tanzania, ISBN 9987-617-93-X: Mzumbe University.

Nochi, M. (1998). Struggling with the Labeled Self: People with Traumatic Brain Injuries in Social Settings. Qualitative Health Research, 8, 665-681. http://dx.doi.org/10.1177/104973239800800507

Ojha, A., Palvia, S., \& Gupta, M. P. (2008). A Model for Impact of E-Government on Corruption: Exploring Theoretical Foundations. In J. Bhattacharya (Ed.), Critical Thinking in E-Governance (pp. 160-170). New Delhi: Gift Publishing.

Oman, C. (2000). Policy Competition for Foreign Direct Investment: A study of Competition among Governments to Attract FDI: OECD.

Page, S. J., \& Hardyman, R. (1996). Place marketing and town centre management: A new tool for urban revitalization. Cities, 13(3), 153-164. http://dx.doi.org/10.1016/0264-2751(96)00002-9

Sannarnes, M., Henriksen, H., \& Andersen, K. V. (2006). The E-Government Melting Pot: Lacking New Public Management and Innovation Flavor. Lecture Notes in Computer Science, 4084, 25. http://dx.doi.org/10.1007/11823100_3

Schedler, K., \& Scharf, M. C. (2001). Exploring the Interrelations between Electronic Government and the New Public Management. Paper presented at the 13E Conference, Zurich

Scholl, H. (2006). Is e-government research a flash in the pan or here for the long shot. Lecture Notes in Computer Science, 4084, 13. http://dx.doi.org/10.1007/11823100_2

Schuppan, T. (2008). E-Government in developing countries: Experiences from sub-Saharan Africa. Government Information Quarterly, 26(1), 118-127. http://dx.doi.org/10.1016/j.giq.2008.01.006

Sixsmith, J., \& Murray, C. D. (2001). Ethical Issues in the Documentary Data Analysis of Internet Posts and Archives. Qual Health Res, 11(3), 423-432. http://dx.doi.org/10.1177/104973201129119109

Standifird, S. S., \& Marshall, R. S. (2000). The Transaction Cost Advantage of Guanxi-Based Business Practices. Journal of World Business, 35(1), 21. http://dx.doi.org/10.1016/S1090-9516(99)00032-2

Ulaga, W., Sharma, A., \& Krishnan, R. (2002). Plant location and place marketing: understanding the process from the business customer's perspective. Industrial Marketing Management, 31(5), 393-401. http://dx.doi.org/10.1016/S0019-8501(00)00151-6

UN, \& ASPA. (2002). Benchmarking E-government: A Global Perspective: New York, UN Publication.

Wang, L., Bretschneider, S., \& Gant, J. (2005). Evaluating Web-based e-government services with a citizen-centri approach. Paper presented at the Proceedings of the 38th Hawaii International Conference on System Sciences. http://dx.doi.org/10.1109/HICSS.2005.252

Wells, L. T. (1999). Revisiting Marketing a Country: promotion as a Tool for Attracting Foreign Investment. Harvard Graduate School of Business Administration. [Online] Available: http://www.ifc.org/ifcext/fias.nsf/

Wells, L. T., \& Wint, A. G. (1990). Marketing a country: promotion as a tool for attracting foreign investment. FIAS Occasional Paper No. 1. Washington. 
Wells, L. T., \& Wint, A. G. (2000). Marketing a Country: Promotion as a Tool for Attracting Foreign Investment. FIAS occasional paper No.13. Washington: The International Finance Corporation, the Multilateral Investment Guarantee Agency, and the World Bank.

Williamson, O. E. (1985). The Economic Institutions of Capitalism: Firms, Markets, Relational Contracting. London: Collier Macmillan.

Winzelberg (1997). The analysis of an electronic support group for individuals with eating disorders. Computers in Human Behavior, 13(3), 393.

World Bank (2008). Doing Business 2009, Comparing Regulation in 181 Economies: Country Profile for Tanzania. Washington.

Yin, R. K. (1994a). Case Study Research: Design and Methods (2nd ed.). Thousand Oaks: Sage.

Yin, R. K. (1994b). Discovering the Future of the Case Study Method in Evaluation Research. Evaluation Practice, 15(3). http://dx.doi.org/10.1016/0886-1633(94)90023-X

Zacharakis, A. L. (1997). Entrepreneurial Entry into Foreign Markets: A Transaction Cost Perspective. Entrepreneurship: Theory \& Practice, 21(3), 23-39.

Table 1. Company Description

\begin{tabular}{|l|l|l|l|}
\hline Company & Investor's nationality & Plan of ownership & Sector(s) of interest \\
\hline A & India & Whole owned & Manufacturing \\
\hline B & Norway, UK \& Tanzania & Joint Venture & Bio-Fuel industry \\
\hline C & India & Whole owned & Mining \\
\hline D & Netherlands & Unknown & Poultry Industry \\
\hline E & UAE & Joint Ventures & Agriculture \& Mining \\
\hline F & Netherlands & Whole owned & Tourism \\
\hline G & Kenya, Tanzania & Joint Venture & Agriculture \\
\hline
\end{tabular}

Source: Authors' construct

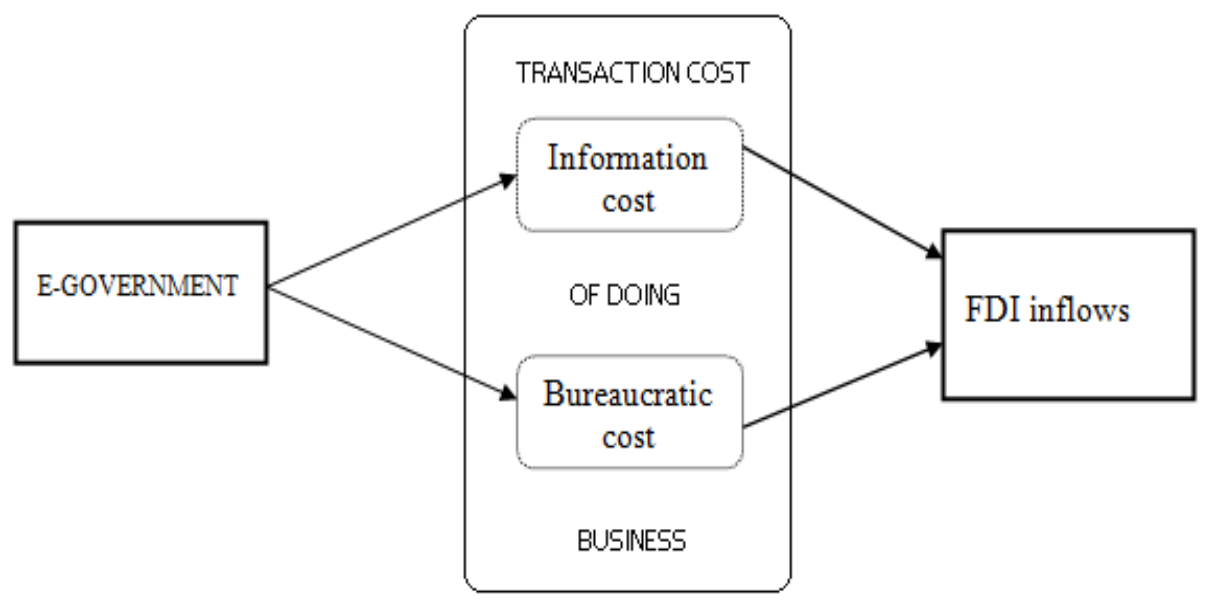

Figure 1. Conceptual Model (Source: Authors' construct) 


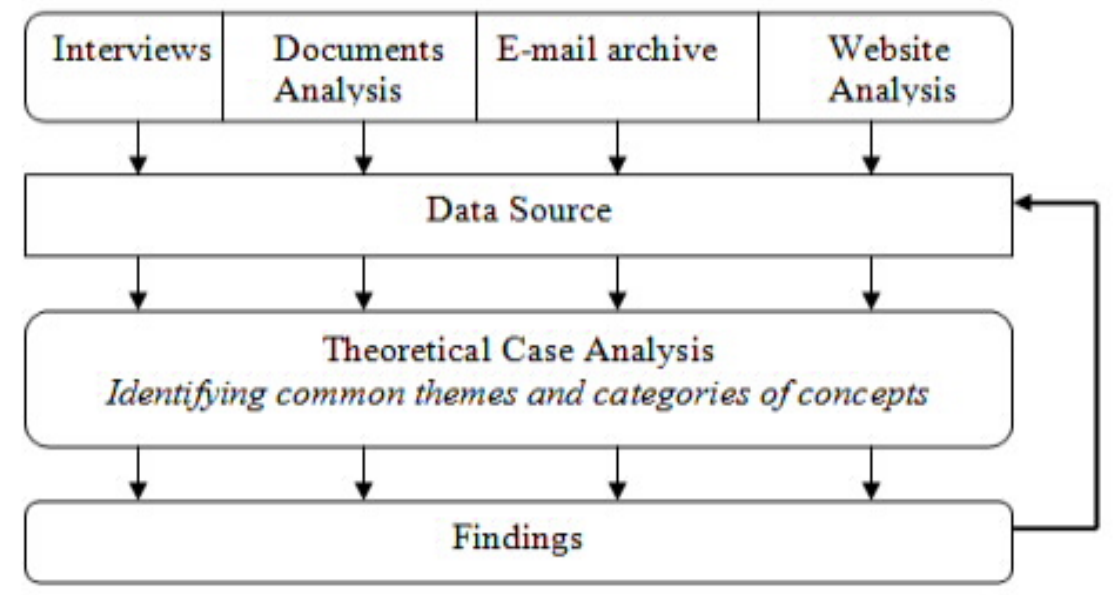

Figure 2. Research Process (Source: Authors' construct)

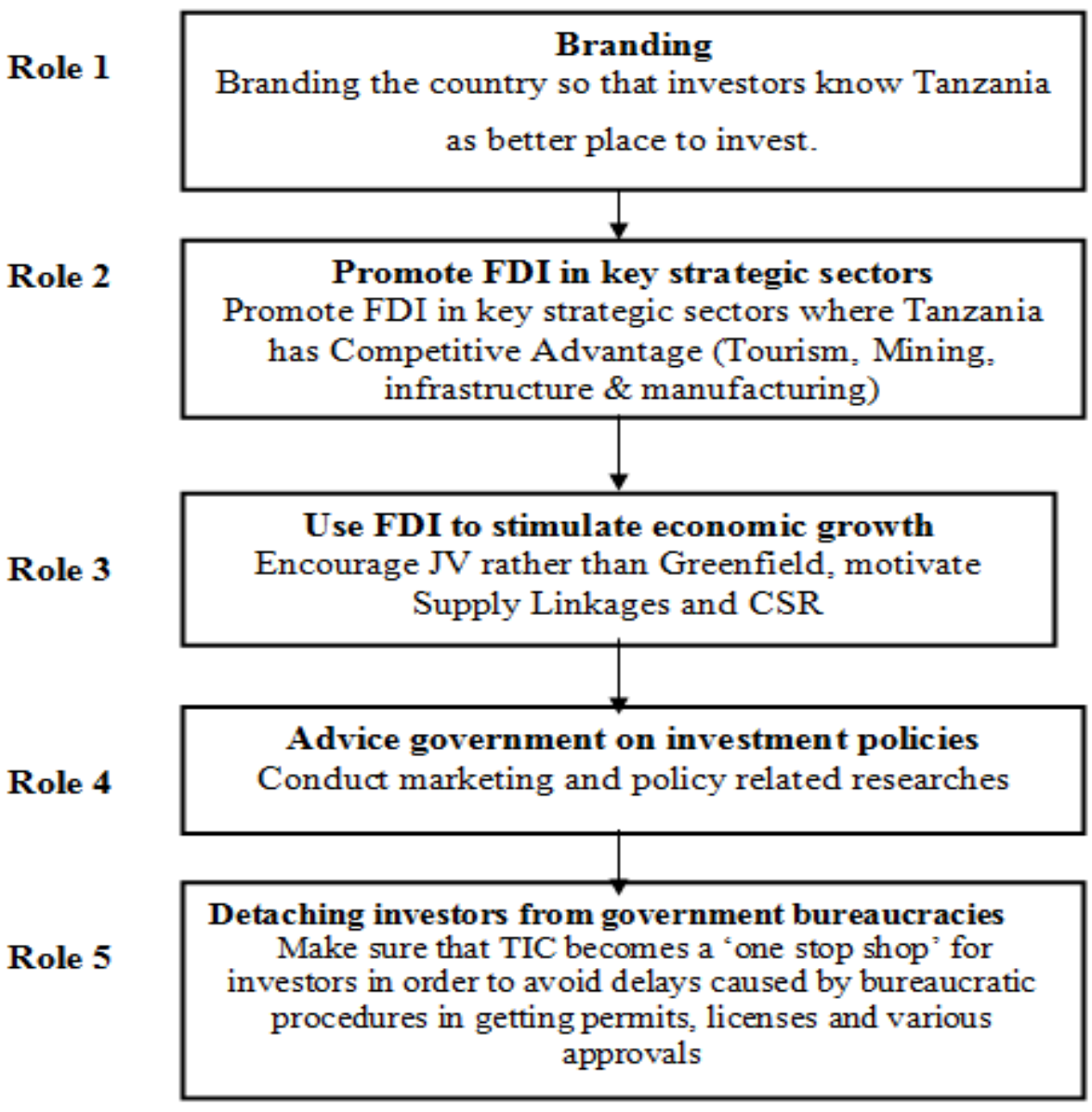

Figure 3. The Top 5 Functions of Tanzania Investment Centre (TIC) 